\title{
An Intensive Academic English Course for Generation1.5 ELLs Bound for Postsecondary Studies: Curriculum Design, Development, and Implementation
}

Katie Crossman and Geoffrey Pinchbeck

Immigrants and the children of immigrants who have completed their schooling in Canadian school settings, commonly referred to as Generation 1.5, are increasingly identified in the research literature as academically at risk due to inadequately developed academic language proficiency and learning strategies. This article describes the design, development, and implementation of a curriculum that targets the academic needs of these students as they transition from high school to university. A thematically integrated design is adopted for the purposes of contextualizing the academic demands of science and engineering, business, and social sciences and humanities. Preliminary insights from a prototype iteration of the curriculum are presented.

Les recherches indiquent de plus en plus que les immigrants et les enfants d'immigrants qui ont complété leur scolarité dans des écoles canadiennes (qu'on appelle couramment la génération 1,5) sont à risque sur le plan académique en raison de stratégies académiques axées sur la compétence langagière et l'apprentissage qui ne sont pas suffisamment développées. Cet article décrit la conception, le développement et la mise en œuvre d'un programme d'études visant les besoins académiques de ces élèves lors de leur passage de l'école secondaire à l'université. Sa conception représente une intégration thématique de sorte à répondre aux besoins des exigences académiques des domaines suivants : science et génie; affaires; et sciences sociales et humanités. Nous présentons des résultats préliminaires d'un prototype du programme d'études.

Developing academic proficiency in English is a gradual, protracted process. Generation 1.5 describes a diverse and rapidly growing population of schoolaged immigrant students, many of whom are developing users of language and still acquiring academic language proficiency (Cummins \& Man YeeFun, 2007) as they complete their high school graduation requirements (Garnett, in press; Gunderson, 2007; Roberge, Siegal, \& Harklau, 2009; Rumbaut \& Ima, 1988; Toohey \& Derwing, 2006). Increasingly, children of immigrants to Canada are pursuing university education at higher rates than their 3rdgeneration Canadian peers (Abada, Hou, \& Ram, 2008) and also graduating at higher rates (Abada, Hou, \& Ram, 2009). However, studies that focus on 
the academic trajectories of this profile of learner suggest that significant numbers of them are at academic risk in university settings (Douglas, 2010; Grayson, 2009; Roessingh \& Douglas, 2011). Furthermore, a number of studies indicate that the performance of permanent resident non-native Englishspeakers (NNESs) is well below that of their native-speaker (NS) classmates (Douglas; Gerardi, 1996; Kilbride \& D'Arcangelo, 2002). A key factor that underlies various indices of academic vulnerability such as course failure/repeat, withdrawal, and marginal GPA is insufficient academic language competence to engage with the objectives of the university curriculum.

A brief survey of the current curriculum reveals that the Alberta public school system deemphasizes academic literacy and only minimally addresses literacy in general after junior high school (Government of Alberta, 2011a, 2011b). This literacy loss is particularly evident in the academic-track high school English language arts curriculum (ELA-1). This grade 12 course, required for university admission in Alberta (Government of Alberta, 2003) focuses on critical analysis of literary texts (Government of Alberta, 2011c) without addressing the development of advanced academic language. The assumption in Alberta Education that students have attained literacy competence in support of success in university before entry into high school and/or have developed incidentally without the programmed intent of the school system is flawed. Our data identify students, who are currently graduating from high school and entering university with reading and writing proficiency well below the academic levels required for university success. This literacy gap appears to contribute to these students' unpreparedness to meet the linguistic challenges of their university courses.

This work is motivated by the belief that in enhancing the linguistic resources of Generation 1.5 learners, who are academically at risk at the transition point from high school to university, will have a tangible effect on immediate and long-term academic performance. We describe an intensive summer English for Academic Purposes (iEAP) program for universitybound Generation 1.5 learners in need of academic support.

We begin with a brief definition of academic language as it pertains to Generation 1.5s who are still developing their language. Then we describe the process of identifying the learning needs of Generation 1.5s in university, followed by the design and development of the iEAP curriculum. Finally, we present preliminary insights that result from a prototype iteration of the curriculum implemented in summer 2010.

\section{A Definition of Academic English}

According to Cummins and Man Yee-Fun (2007), academic English is the language of school that students must interpret and use fluently, in contrast to conversational language, which may be limited to a predominantly oral vocabulary of approximately 3,000-5,000 high-frequency words (Cummins, 
1982, 1994). Academic English is characterized by complex, symbolic, metaphoric, and technical vocabulary that includes specialized uses of common words in addition to a vast and deep knowledge of low-frequency vocabulary. Cummins and Man Yee-Fun (2007) define academic English as "knowledge of the less frequent vocabulary of English as well as the ability to interpret and produce increasingly complex written language" and suggest that extensive reading and writing across multiple genres is necessary for the development of academic language.

Academic English at the university level involves receptive (reading) and productive (writing) skills. The volume of course material, its complexity, and demands that engage the student in independent thought with little if any support suggest that time management and learning strategies are vital elements of curriculum design.

\section{Identification of the Needs of Generation 1.5s at Univer- sity/Academic Demands of First-Year University}

This project began in December 2009 with an environmental scan to determine the core academic demands of university-level studies, particularly in the faculties that tend to attract high numbers of Generation 1.5 registrations: Engineering, Sciences, Social Sciences, and Business (Douglas, 2010). Although studies are available that catalogue the skills required in university more generically such as writing research papers, taking notes from lectures, and giving presentations (Cheng, Myles, \& Curtis, 2004), a goal of this phase of the work was to understand the difficulty level and the context in which these skills are required. Considerable time, therefore, was devoted to reviewing course materials (course outlines, readings, textbooks, examinations, assignments), speaking with faculty members, and sitting in on lectures and labs. In parallel, this process also allowed us to explore possibilities for the specific thematic content in which the iEAP course materials could be embedded.

The needs-analysis process led to identification of a multitude of academic tasks and strategies that undergraduate students need to master during their program. Some of these were common to all the faculties of interest, whereas some were unique to a given faculty. For example, all faculties required students to read textbooks, attend lectures, and take notes, whereas writing genres varied considerably among programs.

The specific language needs of Generation $1.5 \mathrm{iEAP}$ learners were at first approximated by analyzing Effective Writing Test essays (Douglas, 2010) and standardized vocabulary reading tests pre-program. This information was the driver behind our next steps: curriculum design and development. 


\section{Curriculum Design and Development}

For the purposes of this project, a curriculum framework (LearningByDesign, Roessingh, 2007) was adopted that operationalizes general principles of a language-through-content (LTC) approach, using the rubric of thematically integrated content as a strategy for organizing the curriculum. This framework reflects a strong version of LTC wherein it is the learning needs of the students (language, concept information, strategies) rather than the content that drives the curriculum design. These learning needs must be taught directly and explicitly if Generation 1.5s are to benefit from the instructional efforts of classroom practitioners.

Thematic organization permits sustained attention to a single topic and ensures the gradual increase in rigor of the learning targets through spiraling and scaffolding (Vygotsky, 1986), recycling of key vocabulary, and integrating language skills/concepts and learning strategies in the context of the theme topic (Pally, 2001). Themes are often generative and flexible enough to allow for application of the core learning objectives to a novel essential question, still in the thematic framework.

From a perspective of curriculum design and development, thematic organization is an ideal vehicle for developing interrelated learning modules. Aligning with the demands of the following broad disciplines-(a) social sciences and humanities, (b) science and engineering, and (c) business-three modules were developed in the theme of urban development. Each content area was created so that one module linked naturally to the next, deliberately allowing for both vocabulary and concepts from earlier classes to be recycled and revisited. Students were first introduced to the history and overarching urban social issues so that they could gain a better grasp of the more complex subject matter presented later in the program. They subsequently learned about the scientific and technological issues related to some urban problems (in the science component) and were finally asked to imagine a business in which a real product or service could offer a solution to some of these problems (in the business content area). By looking at the subject of urban development from a variety of perspectives, students were able to find similarities to and differences between disciplines and understand and apply a variety of real-life approaches.

A synthesis of the needs assessment and the theme of urban development allowed drafting of an outline of the major written and spoken assignments; this blueprint provided the foundation from which a dynamic design process could begin (see Figure 1) that ultimately led to the selection of materials and the development of detailed lesson plans.

The LearningByDesign framework (Roessingh, 2007) encourages a dynamic approach to curriculum work, seeking ultimately a balanced, well-integrated curriculum that is learner-centered. Curriculum work is rarely a linear process: the framework allows for multiple entry points. Thus sometimes our work was focused on developing learning tasks, at other times on 
Theme: Plan-It Calgary - 3 Units of Inquiry \& Schedule

\begin{tabular}{|c|c|c|c|c|c|}
\hline \multicolumn{6}{|c|}{ Pre-Testing } \\
\hline \multirow{2}{*}{$\begin{array}{l}\text { Content Area } \\
1 \\
\text { Social sciences } \\
\text { and Humanities }\end{array}$} & \multicolumn{2}{|c|}{$\begin{array}{c}\text { 1st period } \\
\text { (Academic Writing } \\
\text { \& Grammar) }\end{array}$} & \multicolumn{2}{|c|}{$\begin{array}{c}\text { 2nd period } \\
\text { (Academic Reading Comprehension \& } \\
\text { Proficiency) }\end{array}$} & \multirow{2}{*}{$\begin{array}{c}\begin{array}{c}\text { 3rd period } \\
\text { (Academic } \\
\text { Communication } \\
\text { Skills) }\end{array} \\
\\
\text { Presentation 1 } \\
\text { (City Council Debate) }\end{array}$} \\
\hline & $\begin{array}{c}\text { Report } \\
1\end{array}$ & Essay 1 & $\begin{array}{l}\text { Selected university text-book } \\
\text { readings: History, Design; Plan-It } \\
\text { Calgary documentation }\end{array}$ & $\begin{array}{l}\text { Extended } \\
\text { Reading } 1\end{array}$ & \\
\hline $\begin{array}{c}\text { II } \\
\text { Science and } \\
\text { Engineering }\end{array}$ & \multicolumn{2}{|c|}{$\begin{array}{c}\text { Lab / Scientific } \\
\text { Report }\end{array}$} & $\begin{array}{l}\text { Selected university text-book } \\
\text { readings: ecology, chemistry, } \\
\text { engineering; } \\
\text { Plan-It Calgary documentation }\end{array}$ & $\begin{array}{l}\text { Extended } \\
\text { Reading } 2\end{array}$ & $\begin{array}{l}\text { Presentation } 2 \\
\text { (Research Report) }\end{array}$ \\
\hline $\begin{array}{l}\text { III } \\
\text { Business and } \\
\text { communications }\end{array}$ & \multicolumn{2}{|c|}{$\begin{array}{l}\text { Market Analysis / } \\
\text { Business Plan }\end{array}$} & $\begin{array}{l}\text { Selected university text-book } \\
\text { readings: Finance, Business, } \\
\text { Communications; Plan-It Calgary } \\
\text { documentation }\end{array}$ & $\begin{array}{l}\text { Extended } \\
\text { Reading } 3\end{array}$ & $\begin{array}{l}\text { Presentation } 3 \\
\text { (Business Plan) }\end{array}$ \\
\hline
\end{tabular}

Figure 1. The major assignment schedule of the 120-hour/6-week iEAP program.

Each of the three content-area modules (I. social sciences and humanities, II. science and engineering, III. business and communications) consisted of 40 hours of class time and in addition approximately 40 hours of assigned work. The major assignments in each module were derived from the university needs analysis. The remainder of the program was designed in part with the objective of enabling student success on all these major assignments.

finding, modifying, and creating suitable content. We kept assessment in mind to ensure that student growth and desired outcomes could be quantified, which was done largely through pre- and post-testing (see Findings below).

Figure 2 illustrates the overall curriculum blueprint for the first two-week module (social sciences and humanities content area). It reflects a design based on a sense of pedagogical intent and an awareness of learners' needs.

\section{iEAP Materials Development}

Core materials needed to meet several criteria, which were at times in conflict with one another. For example, in order for target language to be meaningful, it needs to be embedded in a context that is accessible to the learner. How- 


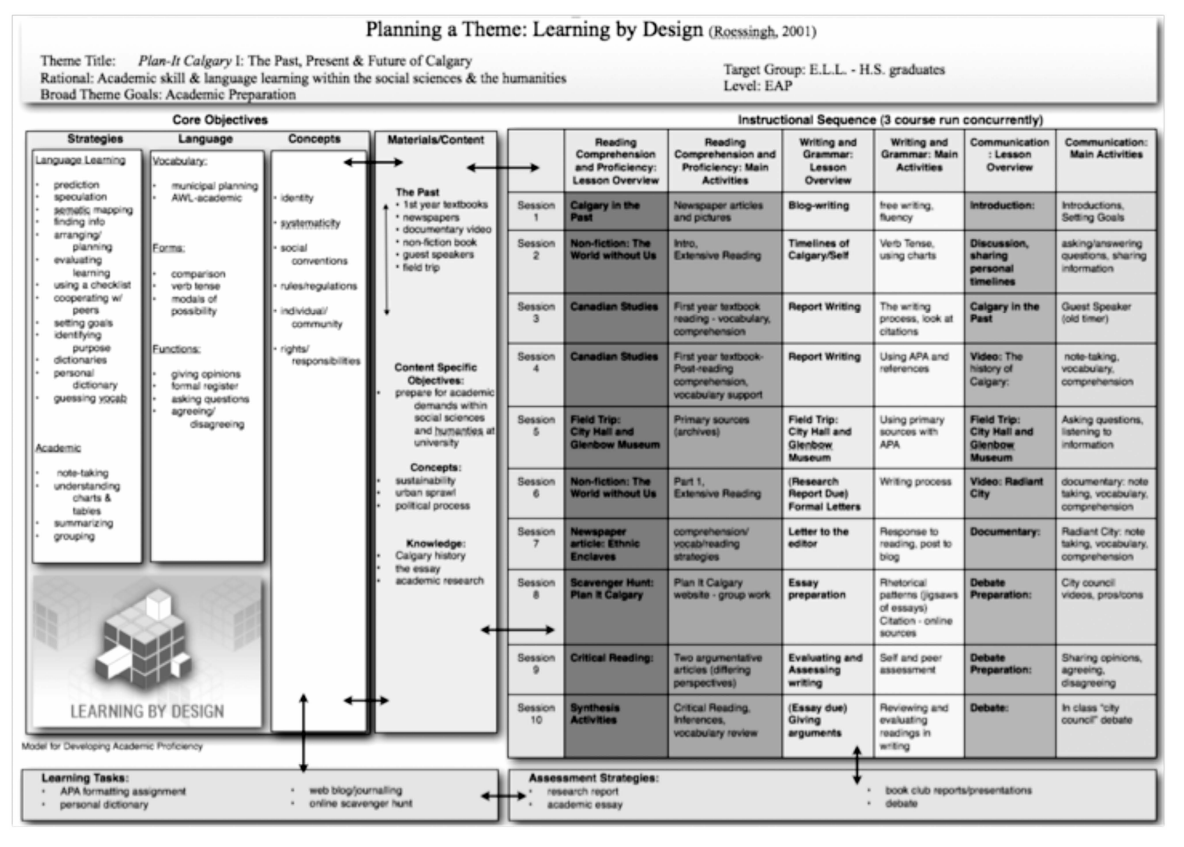

Figure 2. LearningByDesign social science and humanities template.

This outlines the main goals and activities for the first two-week component of $i E A P$. The large panel on the right-hand half of the template outlines the syllabus for this two-week module. Each session consists of four hours of instruction for three courses: (a) reading, (b) writing, and (c) oral communication. In the panels on the left, the syllabus is aligned with underlying objectives in academic and language-learning strategies, explicit language targets (vocabulary, forms, and functions), and broad concepts related to the specific academic subjects and the human condition in general. The middle panel outlines the materials and specific content that will be used as the vehicle of instruction. Finally, in the bottom panels, formative (learning tasks) and summative (assessment strategies) assessment for the module are outlined. Similar templates were created for each of the remaining two iEAP program modules in science and engineering and business and communications (not shown).

ever, materials that are rich in new vocabulary are incrementally more difficult for learners to engage with as the number of unknown vocabulary items encountered increases. In practice, authentic materials that contain new vocabulary are at the same time inaccessible to the language-learner because new words are not found in a suitably comprehensible context (for a discussion of this dilemma, see Cobb, 2007, 2008).

Indeed, an examination of first-year textbooks indicated a vast disparity between the actual reading levels of our students and the reading levels ex- 
pected of university students. First-year NS students generally represent the upper quintile of the high school population and can generally be expected to read materials well above grade equivalent (GE) 12. Our assessment of first-year-university reading demands reflected a threshold as high as GE 17.5, challenging, therefore, even for the average NS first-year student. NNES, by comparison, generally read at an approximate GE 9 , as estimated by their ELA 30-1 diploma exam marks (Roessingh, 2008). Clearly NNES will be overwhelmed almost immediately by the volume, density, and rigor of reading on arrival at university (Roessingh \& Douglas, 2011).

Despite these inherent challenges, by working within the single theme of urban development, where concepts and academic and domain-specific vocabulary would be repeatedly encountered, it was possible to progress from newspaper-level materials, which are typically written at grade 9 level (GE 9 ), and then spiral the materials up to the level of authentic first-year texts. The free online vocabulary-profiling tool Web VP English BNC-20 v3.2 (Cobb, n.d.; Heatley \& Nation, 1994) allowed us to evaluate potential iEAP course materials and to choose vocabulary items that would be most appropriate to teach explicitly.

\section{Target Vocabulary}

Once course materials had been chosen, we identified target academic and discipline-specific language from these materials. Academic vocabulary items were chosen for explicit instruction if they met the following criteria: (a) they occurred frequently in the course materials (preferably five times or more); and (b) they were not among the first most common 2,000 families of the British National Corpus (BNC). In addition, words that met these criteria and were also on the Academic Word List (Coxhead, 2000) were given priority as vocabulary targets. This process assisted in the identification of some domain-specific vocabulary, which despite not consisting of primary program target lexical items was used strategically in the scaffolding of reading and listening tasks.

When developing exercises for language development, we kept in mind our goal to increase both the breadth and the depth of students' vocabulary. Thus low-frequency target word families (e.g., BNC 8K+) were included to promote breadth of knowledge and other mid-frequency words that might be familiar (e.g., BNC 3K+) were included to promote depth. Depth of vocabulary knowledge may enhance students' writing and flexibility by reducing errors in word choice.

\section{Implementation}

Prototype projects are an important part of research because they provide valuable preliminary data, as well as insights and information about the research methods, testing instruments, and data analysis techniques (van Teijlingen \& Hundley, 2001). Here we provide some preliminary findings from 
the first implementation of the iEAP curriculum. The 120-contact-hour iEAP pilot project was run at the University of Calgary over six weeks in summer 2010 with a small but diverse group of students who were transitioning to the University from local high schools. They had learned about the iEAP program from recruitment information distributed to the schools just before graduation from high school. This prototype implementation allowed us to evaluate the program, gave us first-hand experience with the students, and brought to light other issues that we had not foreseen when developing the

\section{PRE-TEST $\longrightarrow$ POST-TEST}

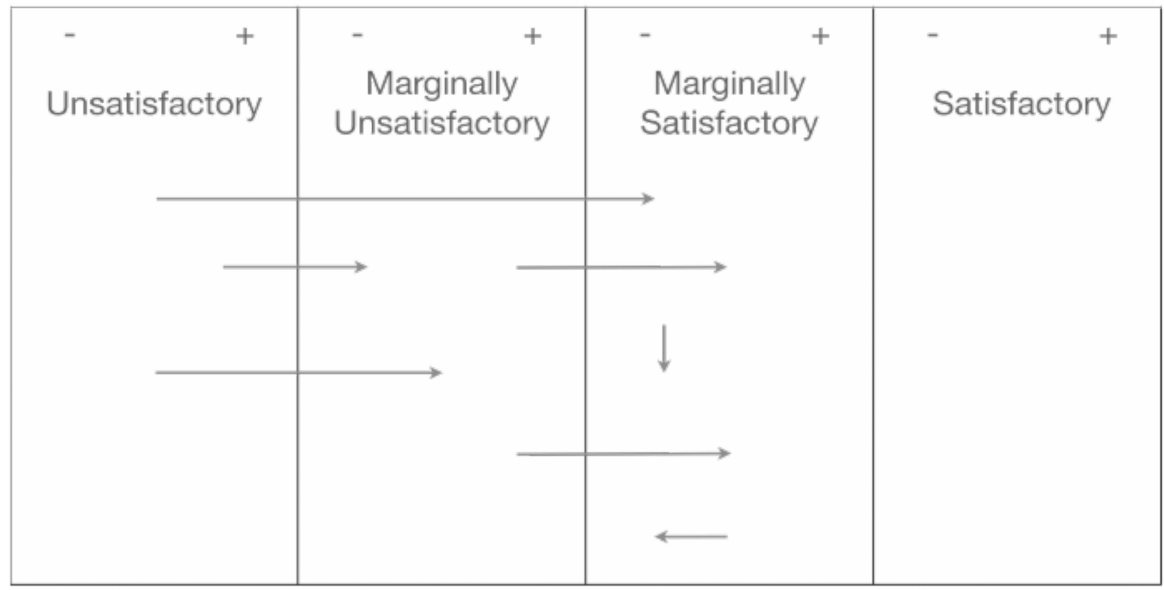

Figure 3. Students' progress in an academic persuasive essay after 6 weeks.

Each arrow represents the writing sample results of each student where the tail and the head of the arrow represent the pre-and post-course scores respectively. Varied prompts on an academic topic were used for the pre-and post-tests. Essays scored according to the University of Calgary Effective Writing Test (EFWT) rubric were double-marked: one scorer provided a holistic rating of the essay: (a) unsatisfactory, (b) marginally unsatisfactory, (c) marginally satisfactory, (d) satisfactory; the latter two scores represent a passing performance. The second scorer used a detailed rubric from which total scores were calculated. The number and type of writing errors in each of several categories were totaled, and a formula allowed the second scorer to arrive at one of the four scores above (EFWR, 2003). In cases where the first and second scorers' results differed, a third assessor was used. The markers were given no information about the iEAP program or the students in the pilot program. An sample text of a student who moved from pre-test score of marginally unsatisfactory to a post-test marginally satisfactory is presented in the Appendix. 
curriculum. The pretesting, for example, showed us that the students' reading and vocabulary levels were lower than anticipated (see Table 2) so greater support and scaffolding had to be implemented as needed. We also discovered that many of the students had been using coping mechanisms such as plagiarism. When we identified this problem during the pilot, we integrated activities for learning about the meaning of plagiarism and developing strategies to avoid it. Direct instruction in paraphrasing, synthesizing, and summarizing information, along with the correct citation and referencing of research sources, virtually eliminated the issue of plagiarism.

\section{Findings}

In order to evaluate the effectiveness of the iEAP curriculum, we employed a number of pre- and post-tests to assess students' writing, reading comprehension, and receptive and productive vocabulary. We summarize some of our findings below.

\section{Academic Writing}

We asked the students to compose an academic-style persuasive essay. The essays were then blind-marked by an independent assessor using a traitbased error-coding sheet for the University of Calgary Effective Writing Test (EFWR, 1993). Figure 3 shows the final mark for the iEAP students' essays before and after the iEAP program. As the figure indicates, five of seven students improved, one passing student regressed slightly, and one stayed at the same level.

Table 1

Error Rates in Students' Essays Before and After the iEAP Program

\begin{tabular}{lccccc}
\hline Error Rate-Type & pre & post & $T$ & $d f$ & Sig. (2-tailed) \\
\hline Punctuation and Spelling & $0.89 \%$ & $0.18 \%$ & 2.23 & 6 & .067 \\
Vocabulary and Grammar & $8.9 \%$ & $5.9 \%$ & $2.57^{*}$ & 6 & .042 \\
Organization & $0.71 \%$ & $0.27 \%$ & $2.89^{*}$ & 6 & .028 \\
Overall & $10.5 \%$ & $6.37 \%$ & $3.42^{*}$ & 6 & .014 \\
\hline
\end{tabular}

${ }^{*} p<0.05$ (2-tailed).

Writing errors were tabulated and divided by the total number of words. Trained, experienced markers in using the now defunct University of Calgary Effective Writing Test scoring sheets blind-marked pre- and post-iEAP program academic essays. The score sheet provides error frequency information in major categories that comprise 57 error types and 156 sub-types. Repeated instances of the same error type are counted as only one error (EFWR, 1993). Error rates in each major category were calculated by dividing the number of error types by the total number of words (tokens) in the essay. In some cases, error categories were combined; for example, Organization error rates represent the combined errors from Paragraph Error and Essay Structure. Differences between preand post-iEAP program results were compared using the paired samples t-test. 


\section{Writing Errors in the Essays}

Although the total essay score findings illustrate that iEAP students for the most part made overall improvements in academic writing, we also wished to know specifically where these improvements were made. The numbers of errors in various error categories were divided by the total number of words (tokens) in each essay to give the error rates as shown in Table 1. Students showed significant improvements in all categories where errors were relatively frequent: grammar, organization, and vocabulary; and class averages on all remaining categories were better on the post-program essays (not shown). Thus the improvement in overall essay marks is attributed to general improvements across the entire range of essay rubric categories.

\section{Vocabulary}

Engber (1995) documented the relationship between vocabulary knowledge, reading comprehension, and academic achievement. On standardized and in-house tests immediately before and after the iEAP program, students showed significant gains in receptive and productive vocabulary. One of the tests that we used was the Gates MacGinitie Reading Test (2nd ed., MacGini-

Table 2

Gates MacGinitie Vocabulary (Grade Levels) Before and After iEAP Program

\begin{tabular}{lccc}
\hline Student & \multicolumn{3}{c}{ Vocabulary Grade Level } \\
\hline & Pre & Post & Difference \\
\hline 1 & 5.0 & 7.3 & 2.3 \\
2 & 10.6 & 9.1 & -1.5 \\
3 & 4.6 & 7.9 & 2.3 \\
4 & 5.7 & 8.1 & 2.4 \\
5 & 7.6 & 9.3 & 1.7 \\
6 & 8.1 & 8.8 & 0.7 \\
7 & 7.3 & 9.3 & 2.0 \\
Class Average & 6.9 & 8.5 & $* 1.6$ \\
\hline
\end{tabular}

${ }^{*} t(6)=-2.64 ; p=.029$, two-tailed.

This test provides a normalized grade level that corresponds to public school grade levels. Therefore, a grade 5 result on this test means that the examinee has roughly the same vocabulary as the average grade 5 student. Level E forms 3 and 4 (2nd Canadian Edition Grade 9 level) of the Gates-MacGinitie reading comprehension and vocabulary test were used for the pre- and post-tests respectively (MacGinitie \& MacGinitie, 1992). Differences were compared using a paired-sample t-test. The iEAP designers had no knowledge of this test or its contents before the test was administered. 
Table 3

Essay Vocabulary Use and Writing Errors

\begin{tabular}{lccccc}
\hline & pre & post & $t$ & $d f$ & Sig. (2-tailed) \\
\hline $\begin{array}{l}\text { \% Vocabulary use beyond } \\
\text { BNC 2,000-word band }\end{array}$ & $8.84 \%$ & $12.76 \%$ & $-3.5^{\star}$ & 6 & .013 \\
\begin{tabular}{l} 
Writing Error rate \\
\hline
\end{tabular} & $10.5 \%$ & $6.4 \%$ & $3.4^{*}$ & 6 & .014 \\
\hline
\end{tabular}

${ }^{*} p<.05$ (2-tailed).

Percentage of student essay vocabulary beyond the 2,000 most common words in the BNC compared with total writing error rates. The pre- and post- numbers represent class averages $(n=7)$ before and after the IEAP program that were compared statistically using the paired sample t-test.

tie \& MacGinitie, 1992), a standardized, widely used test of reading skills and vocabulary knowledge in K-12 educational contexts in North America. As shown in Table 2, the average vocabulary grade level of the iEAP class increased from a grade 6.9 pre-program to a grade 8.5 post-program. Grade levels on this test correspond to the vocabulary of the average Canadian student in that grade.

We also wished to evaluate the degree to which students were able successfully to marshal their apparent increase in vocabulary knowledge by incorporating more sophisticated words into their own writing. Table 3 shows the percentage of vocabulary types from the British National Corpus 3,000 word bands and above in students' essays before and after the iEAP program. The results show that this cohort of iEAP students used more sophisticated vocabulary in their post-program essays, and they did so with significantly fewer writing errors.

\section{Discussion}

Although interpretation of the results of the first pilot course is limited by the small class size $(n=7)$, the pre- and post-test results are nevertheless encouraging. Six of the seven participants showed improvement on every vocabulary test and writing test administered. Significant improvement for the class as a whole was seen in receptive and productive vocabulary competences, as well as in writing assessment, using blind, independent marking (see Figure 3). This was true when we used tests designed in house to test for language that was explicitly taught in the iEAP course and also for a standardized test of vocabulary (see Table 2) where test items were not known to the iEAP course developers or instructor.

Interviews with the iEAP pilot students conducted immediately after the program and at intervals in the intervening 1.5 years have further indicated that these students benefited from the course. One student commented, "I 
learned many interesting things that I didn't know before, improved my writing skills, and learned a bit about my field. I would recommend this course for every ESL student coming to university." These comments are consistent with our view that high-school ELLs can benefit from explicit instruction that targets academic literacy development.

\section{Conclusion}

It is clear that growing numbers of Generation 1.5 students are arriving at university unprepared for the rigors of academic study. Both secondary and postsecondary institutions are on the whole currently not offering the support necessary for adequately preparing at-risk Generation 1.5 students for successful academic studies.

Through our experiences in designing, developing, implementing, and assessing this curriculum, we have seen that the students in our study were indeed capable of making accelerated academic and linguistic gains in a short time. This growth can be attributed to design features of our curriculum work: explicit teaching, scaffolding, recycling of linguistic targets, comprehensible input, and spiraling in the context of theme structure; in short, learning by design. The effect may unlock latent vocabulary acquired through earlier exposure that can be activated and mobilized through direct instruction. We have also learned the importance of the teacher's presence and of creating an environment of trust for a vulnerable learner profile.

Future plans include an array of implementation options for iEAP in university and in high school settings before grade 12 graduation. Research includes ongoing tracking and monitoring to determine the longitudinal effect of iEAP as it influences the academic trajectory of these students throughout university.

Finally, it is clear that for a growing number of Generation $1.5 \mathrm{~s}$, the Canadian-born children of immigrants who have spent their entire K-12 years in local schools, early identification, ongoing and shifting support, and transitional programming at key points are necessary for their educational success. We look forward to opportunities to partner with our K-12 colleagues to plan for the larger K-16 experiences of Generation 1.5s.

Even with the understandings gained from the prototype implementation, there are a number of unanswered questions, and we believe that further research is warranted: (a) to determine better the effects of such an intervention, (b) to understand the needs of at-risk Generation 1.5 students entering Canadian universities, and (c) to prepare at-risk Generation 1.5 students for university in the K-12 system by developing earlier interventions.

\section{Acknowledgments}

We thank the anonymous reviewers for their feedback and Scott Douglas for his expertise and insight. This project was funded by a grant to Hetty Roessingh from Carolyn Dieleman of Alberta Employment and Immigration. 


\section{The Authors}

Katie Crossman is a doctoral (TESL) student in the University of Calgary. Her interests include curriculum development and implementation, EAP, and knitting. She has lived and taught in Canada, Ukraine, Russia, and Mexico.

Geoffrey Pinchbeck is a doctoral student in the Faculty of Education in the University of Calgary. His project focuses on vocabulary use and writing assessment of mainstream high school English language arts classes. He has lived and taught in Alberta, Quebec, Japan, and Saudi Arabia.

\section{References}

Abada, T., Hou, F., \& Ram, B. (2008). Group differences in educational attainment among the children of immigrants. Analytical Studies Branch Research Paper Series. Ottawa: Statistics Canada.

Abada, T., Hou, F., \& Ram, B. (2009). Ethnic differences in educational attainment among the children of Canadian immigrants. Canadian Journal of Sociology, 34, 1-28.

Cheng, L., Myles, J., \& Curtis, A. (2004). Targeting language support for non-native Englishspeaking graduate students at a Canadian university. TESL Canada Journal, 21, 50-71.

Cobb, T. (2007). Computing the vocabulary demands of L2 reading. Language Learning and Technology, 11(3), 38-64.

Cobb, T. (2008). Commentary: Response to McQuillan and Krashen (2008). Language Learning and Technology, 12(1), 109-114.

Cobb,T. (n.d.). Web Vocabprofile [Online computer software] (an adaptation of Heatley and Nation's, 1994 Range). Available: http:/ /www.lextutor.ca/vp/

Coxhead, A. (2000). A new academic word list. TESOL Quarterly, 34, 213-238.

Cummins, J. (1982). Tests, achievement, and bilingual students. Focus, No. 9. Rosslyn, VA: National Clearinghouse for Bilingual Education.

Cummins, J. (1994). The acquisition of English as a second language. In K. SpangenbergUrbschat \& R. Pritchard (Eds.), Kids come in all languages (pp. 36-62). Newark, DE: International Reading Association.

Cummins, J., \& Man Yee-Fun, E. (2007). Academic language: What is it and how do we acquire it? In J. Cummins \& C. Davison (Eds.), International handbook of English language teaching (vol. 15, pp. 797-810). New York: Springer.

Douglas, S.R. (2010). Non-native English speaking students at university: Lexical richness and academic success. Unpublished doctoral dissertation, University of Calgary. Available: https://dspace.ucalgary.ca/bitstream/1880/48195/1/2010_Douglas.pdf

EFWR. (1993). Detailed marking code. The effective writing program. Calgary, AB: University of Calgary.

EFWR. (2003). The assessors' guide for the effective writing test. The effective writing program. Calgary, AB: University of Calgary.

Engber, C.A. (1995). The relationship of lexical proficiency to the quality of ESL compositions. Journal of Second Language Writing, 4, 139-155.

Garnett, B. (in press). A critical review of the Canadian empirical literature: Documenting Generation 1.5's K-12 trajectories. TESL Canada Journal.

Gerardi, S. (1996). The effects of English as a second language on college academic outcomes. Available: ERIC database (ED398946).

Government of Alberta. (2003). Admission requirements. Alberta Education. Available: http://education.alberta.ca/teachers/program/english/info/ela-admission.aspx

Government of Alberta. (2011a). Grade 9: Curriculum summary, 2011/2012. Edmonton, AB: Alberta Education.

Government of Alberta. (2011b). Senior high: Curriculum summary, 2011/2012. Edmonton, AB: Alberta Education. 
Government of Alberta. (2011c). Senior high: Curriculum handbook for parents, 2011/2012. Edmonton, AB: Alberta Education.

Grayson, J.P. (2009). Language background, ethno-racial origin, and academic achievement of students at a Canadian university. International Migration, 47(2), 33-67.

Gunderson, L. (2007). English-only instruction and immigrant students in secondary schools: A critical examination. Mahwah, NJ: Erlbaum.

Heatley, A., \& Nation, P. (1994). Range [Computer software]. Wellington, NZ: Victoria University of Wellington. Available: http://www.victoria.ac.nz/lals/about/staff/paulnation

Kilbride, K.M., \& D'Arcangelo, L. (2002). Meeting immigrant community college students' needs on one Greater Toronto area college campus. Canadian Journal of Higher Education, $32(2), 1-26$.

MacGinitie, W., \& MacGinitie, R. (1992). Gates-MacGinitie reading tests (2nd ed.). Toronto, ON: Nelson Education.

Pally, M. (2001). Skills development in "sustained" content-based curricula: Case studies in analytical/critical thinking and academic writing. Language and Education, 15, 279-305.

Roberge, M., Siegal, M., \& Harklau, L. (Eds.). (2009). Generation 1.5 in college composition: Teaching academic writing to U.S.-educated learners of ESL. New York: Routledge.

Roessingh, H. (2007). LearningByDesign: A tool for curriculum planning for academic language proficiency. Avaailable: http:/ / esllearningbydesign.com

Roessingh, H. (2008). Variability in ESL outcomes: The influence of age on arrival and length of residence on achievement in high school. TESL Canada Journal, 26, 87-107.

Roessingh, H., \& Douglas, S. (2011). English language learners' transitional needs from high school to university: An exploratory study. Journal of International Migration and Integration, 1-17.

Rumbaut, R., \& Ima, K. (1988). The adaptation of Southeast Asian refugee youth: A comparative study. Available: ERIC database (ED299372).

Toohey, K., \& Derwing, T.M. (2006). Hidden losses: How demographics can encourage incorrect assumptions about ESL high school students' success. Research on Immigration and Integration in the Metropolis, Working Paper Series No. 06-11. Vancouver, BC: Vancouver Centre of Excellence.

van Teijlingen, E.R., \& Hundley, V. (2001). The importance of pilot studies. Social Research Update. Available: http:/ / sru.soc.surrey.ac.uk/SRU35.html

Vygotsky, L. (1986). Thought and language. Cambridge, MA: MIT Press. 


\section{Appendix}

\section{Writing sample}

Pre-Test (Concluding paragraph only) "Adnan"

As the world is running out of the fuel, the cost of purchasing the fuel is increasing every day. A fuel is a non renewable resource therefore it cannot be used again. In the future the severe need of the fuel will have dramatic effect on the lives of people. Driving cars will be very expensive and people will have no choice but to use the public transportation as a mean for travelling.

Post-Test (Conclusion) "Adnan"

In order to reduce these problems and eliminate the $\mathrm{CO}_{2}$ emissions it is necessary that the government steps up and take actions to reduce these emissions and at the same time improve the transit industry. As the responsible citizens of the country we have to consider how our actions affect our lives and the environment as well. We have to make choices that are not for our own benefit but for the country as whole. 